Eurasia: Economics \& Business, 1(19), January 2019

DOI https://doi.org/10.18551/econeurasia.2019-01

UDC 332

\title{
URBAN TOURISM BASED ON SOCIAL CAPITAL DEVELOPMENT MODEL
}

\author{
Prakasa Yudha* \\ Department of Business Administration, University of Brawijaya, Indonesia \\ Danar Oscar Radyan \\ Department of Public Administration, University of Brawijaya, Indonesia \\ Fanani Angga Akbar \\ Department of Industrial Engineering, University of Brawijaya, Indonesia \\ *E-mail: y.prakasa87@ub.ac.id
}

\begin{abstract}
The focus of this research is directed at identifying the model of integrative urban tourismbased social capital. The governance model used the Pentahelix approach to develop and integrate various actors in the tourism development process. It is strengthened using a social capital and developing tourist destinations approaches. The social capital approach is used to understand the motivation of community behavior in the development and/or development of urban tourism. The concept of developing tourist destinations is used to see whether the development of urban tourism has met sustainability tourism criteria. The research was conducted in Kampung Warna Warni (Colorful Village) Jodipan, Malang City. The research methodology used was qualitative approach with descriptive analysis techniques. Data collection was done through in-depth interviews with tourism, private, government and community actors. The results of this study indicate that social capital is a major driver in the development of urban tourism. The collaborative governance approach is proven to be able to develop tourism destinations through strengthening social capital in a sustainable manner.
\end{abstract}

\section{KEY WORDS}

Social capital, governance, urban tourism, public service.

The tourism sector development has exhibited its capability to improve community welfare (Lorio and Corsale, 2010; Liu, et. Al, 2018). Various countries endeavor to prioritize tourism sector development. Fan and Hsu (2014) stated that the tourism industry is the sector with the highest growth in the world. From 1990 to 2012, there's a massive increase of tourists visiting Asia. It increased from 55.8 million to 233.6 million (Fan \& Hsu, 2014). Similar phenomenon occurs in Indonesia. In 2017, the number of foreign tourists visiting Indonesia amounted to $10.406,759$ tourists, contributing to Gross Domestic Product of US\$28,208.9 Million or $3.3 \%$ GDP. It created $3,468,440$ or $2.9 \%$ of total work opportunity. However, tourism development in Indonesia is not optimal and needs to be improved. Based on data from the United Nations World Tourism Organizations (UNWTO) and the World Travel and Tourism Council (WTTC), Indonesian tourism competition was ranked 42nd out of 136 countries assessed. The World Conference Forum (2017) also exhibits that the ASEAN level, Indonesia's position is below Singapore (ranked 13), Malaysia (26) and Thailand (34).

The strength of social capital owned by the community has a significant influence on the development of tourism-based entrepreneurship (Johannesson, et al, 2003). Jones (2005) also revealed that social capital factors play an important role in the development of community-based ecotourism. Zhao et al (2011) found that social capital as measured by cognitive capital, structural capital and relational capital owned by the community had a significant influence on the development of entrepreneurship in the tourism sector. The research proves that tourism development initiated by the community is determined by how strong social capital is owned. 
Pomering, et al (2011) stated that in order to create sustainable tourism development, the tourism sector must be able to implement the marketing mix as a whole. Pomering, et al (2011) developed a general concept of the marketing mix based on Kotler \& Keller (2003) suitable for the development of the tourism sector. There are 10 (ten) elements of marketing mix developed by Pomering, et al (2011), namely: product, price, place, promotion, participant, process, physical evidence, packaging, programming, and partnership. The concept is then operationalized in the development of tourism destinations. The Australian Government, for example, states that there is a $5 \mathrm{~A}$ factor playing an important role in strengthening tourism destinations, namely: Attractions, Access, Accommodation, Amenities, and Awareness. Attractions means factors that motivates tourists to leave their place of origin and go to tourist destinations. Access means easy access and transportation to visit tourist sites. Accommodation could be interpreted the readiness of the tourist destination itself and available lodgings. Amenities means services needed by tourists when they are far from tourist attractions such as toilets, restaurants, directions, information centers, and various other supporting facilities. Awareness is determined through people's awareness of tourist destination areas to ensure it possesses positive, friendly and open characteristics for tourist destinations visitors (Tourism Western Australia, 2009). On the other hand, another theory stated that there is a 4A factor in the tourism industry, namely attraction, accessibility, ancillary and amenities (Cooper, 2000; Sugiama, 2014C).

Governance approach is one of the important keys to the successful development of tourism destinations (Bramwell \& Lane, 2011). Pentahelix is a development of governance concept. Pentahelix is a concept to develop and integrate various actors in the development process, in this case, tourism development. According to Carayanis, et., Al. (2012) Pentahelix is an integrative approach by paying attention to the role of 5 (penta) actors in the tourism development process, namely Academician, Business, Community, Government, and Media or often referred to as (ABCGM).

The emergence of a variety of new tourism destinations initiated by the community is an interesting issue to be researched upon. Kampung Warna Warni Jodipan in Malang City is one of the unique destinations which boasts community-based tourism development success. The development of urban tourism is interesting as the urban village is considered a marginalized area. Urban village is a form of settlement in the Indonesian urban areas possessing the following characteristics: the population carries rural life behavior and nature, irregular building structure and environment physical condition, building density and population, lacking base service facilities such as clean water, sewerage, and rainwater, garbage disposal, etc (Fernanda \& Kusuma, 2017). Urban villages are often considered inappropriate and not ready to be developed into urban tourism. Prior to becoming a tourist destination, Jodipan village was one of the slum villages on the banks of the Brantas River in Malang City. This study seeks to explore the governance model of urban tourism development through the role of community social capital.

\section{METHODS OF RESEARCH}

This study used qualitative approaches to describe and explain naturally the development of tourism in Kampung Warna Warni Jodipan, Malang City. Jodipan was originally one of the slums in Malang City. Data collection was conducted through direct observation, documentation and reinforced by in-depth interviews with 3 (three) community members of Kampung Warna Warni Jodipan management, private parties (PT. Indana) and academics (Guys Pro). These parties had provided assistance since the beginning of Kampung Warna Warni Jodipan tourism development. The data collection was conducted on government and community parties involved in Malang City tourism development. Data analysis techniques were carried out in four stages, namely data collection, data reduction, data presentation, and drawing a conclusion (Miles, et al, 2013). 
Eurasia: Economics \& Business, 1(19), January 2019

DOI https://doi.org/10.18551/econeurasia.2019-01

\section{RESULTS AND DISCUSSION}

Social Capital and Initiation of Urban tourism Development. Jodipan village is one of the densely populated settlements in Malang City which is located around the banks of the Brantas River in Malang City. There are around 1,291 inhabitants living in Kampung Jodipan within 5.5 hectares total area (Kelurahan Jodipan, 2011). Most inhabitants are within the urban poor category. Jodipan village is considered a slum. The existing problem is the physical conditions of housing, sanitation, drainage, population density, and building density. According to Law Number 1, the Year 2011 concerning Housing and Settlement Areas article 1 paragraph 13, slum settlements are uninhabitable settlements due to building irregularities, high building density, and the quality of buildings and facilities and infrastructure that do not meet the requirements. Slums usually have a higher level of building density and population compared to ordinary villages. The slums are located around rivers, railroads, etc (Santosa, 2016).

The low level of public awareness in protecting the environment deterred Jodipan Village development. Through the process of understanding and mentoring the Jodipan community continuously since 2013, which was initiated by the Guyspro student team (academics), Jodipan Village is currently one of the tourist destinations in Malang City. The presence of these academics strengthen Jodipan community to rise despite adversity. Academics play a role in providing knowledge, understanding, and assistance to the community about the importance of mutual cooperation in developing urban tourism. Soni Parin, chairman of RW 2, Jodipan Sub district stated:

"The role of academics makes us aware of healthcare and the environment. They also provided an understanding that the need for togetherness and awareness of the entire Jodipan village community to become a clean and neat village"

Furthermore, the role of academics can also be seen from the ability to capture opportunities. Crowded and dirty slum were captured as opportunities to be developed, especially as tourism destinations. Academics also play a role in optimizing their networks to collaborate in developing tourist destinations in the village, as stated by Feri Fadli, Marketing Communication of PT. Indana, a paint company operating in Malang City:

"The idea of academics to make the shabby Kampung Jodipan become one of the tourist destinations is extraordinary. They invited us to develop Jodipan village into Kampung Warna Warni (Colorful Village), and we welcomed a good idea by providing paint to the community".

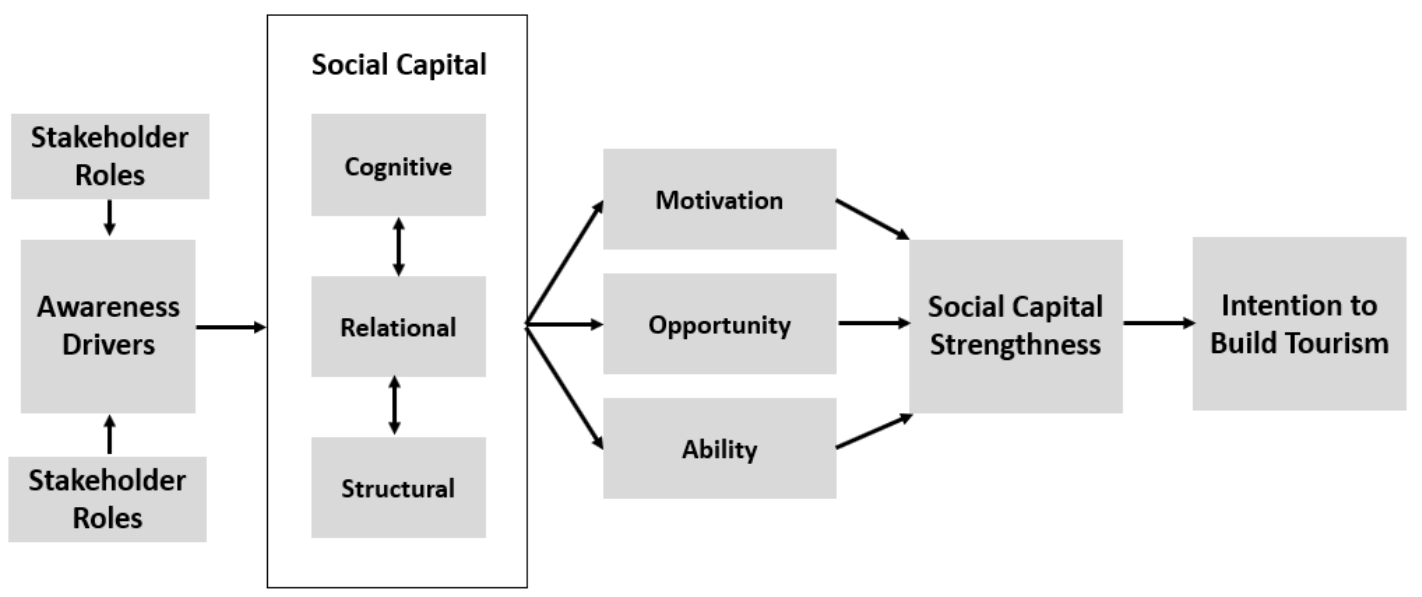

Figure 1 - Initiation for the Construction of a Social Capital-based Urban tourism

This exhibits that academics and/or other stakeholders can be the driving force for initiating the construction of urban tourism. The initiation can be started by strengthening the social capital of the local community as the urban village community possesses strong family ties. Therefore this aspect can become the basic capital in the development of urban tourism. 
Strengthening social capital through strengthening cognitive capital (knowledge and understanding), relational capital (building trust between communities), and structural capital (building community institutions) without losing existing social capital identity. Continuously strengthening social capital will provide and increase community motivation and skills as well as the ability to grasp and develop opportunities. This supports the findings of Jones (2005) which revealed that social capital plays an important role in the success of tourism development. Cognitive and structural capital play a role in synergizing steps, while relational capital plays a role in collaborating with various parties.

The model of stakeholder involvement as a driver of tourism development innovation through strengthening community social capital is described in the figure 1.

Figure 1 exhibits that social capital plays a role in fostering motivation, seizing opportunities, and improving community skills in initiating the development of urban tourism. Nevertheless, the low level of education and prosperity level requires stakeholders to provide knowledge and understanding. The stakeholders have the ability to carry out collaborative transformations. Gursoy, et al (2010) stated that the uniqueness of tourism is the level of dependence on stakeholders.

Stakeholder Engagement in Tourism Destination Development. Stakeholders involved in the development of Kampung Warna Warni Jodipan was identified through the pentahelix approach. These stakeholders were the academics, the private sector (business), community, government, and the media. Each of these stakeholders has a role in developing tourist destinations. Attractions are the main key of tourist destinations. Kampung Warna Warni boasts an iconic colorful village, glass bridges, and various thematic murals. These murals are always updated according to the trending theme. There is stakeholder involvement in conceptualizing and implementing the attraction. PT. Indana (Indana Paint) contributed to in the procurement of paints and glass bridges through its CSR program. The community (Turu Kene) performed mentoring during the making of mural 'turbulence'. The academics (Pro Guys) and the government (Office of Culture and Tourism) play a role in providing community training and assistance in management aspects. Mass media parties endeavored to advertise Kampung Warna Warni through printed and online media. The role of stakeholders is carried out by always involving the community through strengthening social capital.

The second factor in the development of tourist destinations is access. Access is determined from the availability and ease of access to transportation (personal and public) to the destination and directions. Kampung Warna Warni has met the criteria. The tourist destination is located $3 \mathrm{~km}$ from the city center. Therefore tourists have easy access to Kampung Warna Warni Jodipan. The government, Private Sector, and Academics have a role in developing access to Kampung Warna Warni Jodipan.

Accommodation consists of lodging and dining facility. Currently, there are no inns or homestays in Kampung Warna Warni considering the building density. The buildings physical condition does not meet the requirement to be used as homestays or lodgings. On the other hand, there are various dining facilities provided by the Jodipan Community.

Amenity consists of the availability of rest areas and places of worship, toilets, decent parking, souvenir centers, and information centers. The development of amenity is assisted by the government, the community, and academics through various training provided. Accommodation and amenity has an economic impact on the native Jodipan community. They started to open a business establishment in the tourism area.

Public awareness is exhibited through community friendliness towards tourists and public concern for the preservation and development of the Kampung Warna Warni Jodipan. This awareness is formed through strengthening social capital carried out continuously by stakeholders, especially academics and the private sector.

The involvement of various stakeholders in the development of tourist destinations is described in Figure 2.

Figure 2 exhibits that tourism development could not be conducted without stakeholder involvement. Social capital becomes a mediator to strengthen tourism development sustainability. 
Eurasia: Economics \& Business, 1(19), January 2019

DOI https://doi.org/10.18551/econeurasia.2019-01

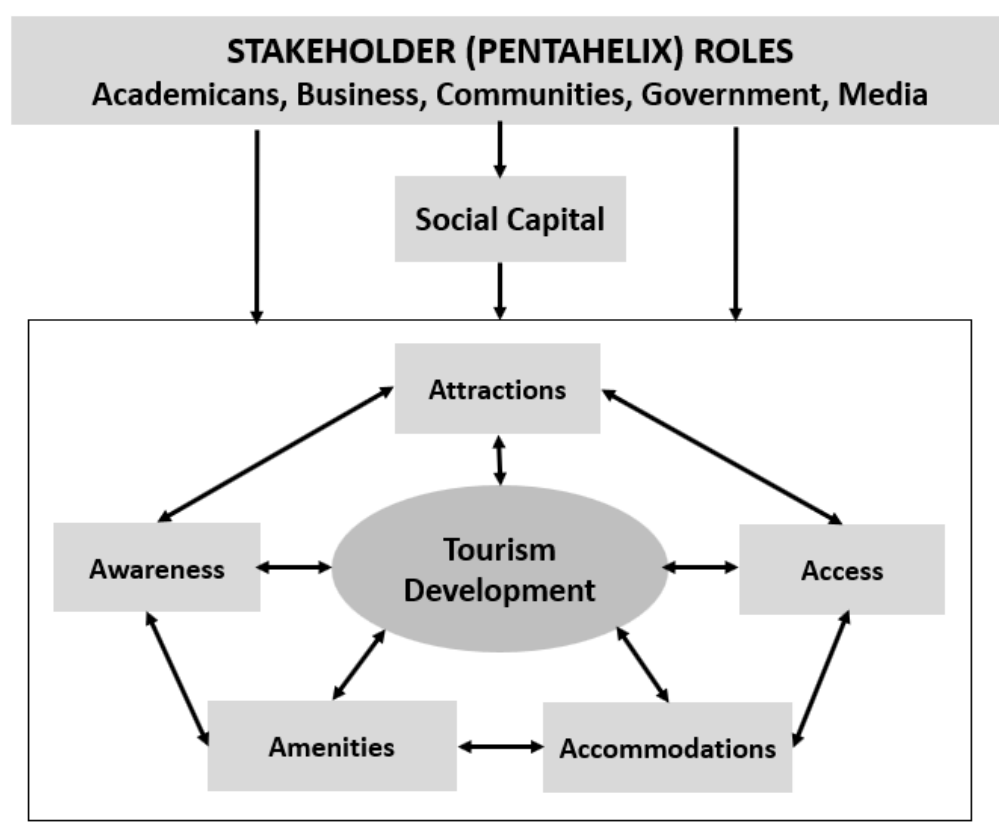

Figure 2 - The relationship between Social Capital and Tourism Destination Development

Tourism Development Governance Model. Good tourism governance will have an impact on the sustainability of tourism, in terms of economic, social and environmental sustainability. The rapid development of Kampung Warna Warni as one of the urban tourism cannot be separated from stakeholder involvement. However, until recently, there has not been a special forum that becomes a means for all stakeholders to collaborate together in developing Jodipan Villag, causing overlapping programs. This research offers a governance model for developing urban tourisms with collaborative governance approaches through strengthening social capital. Actors involved in collaboration consist of academics, business, community, government, and media. They jointly develop urban tourism through strengthening community social capital. Social capital is believed to be a key factor in the development of urban tourism, followed by the development of sustainable tourist destinations.

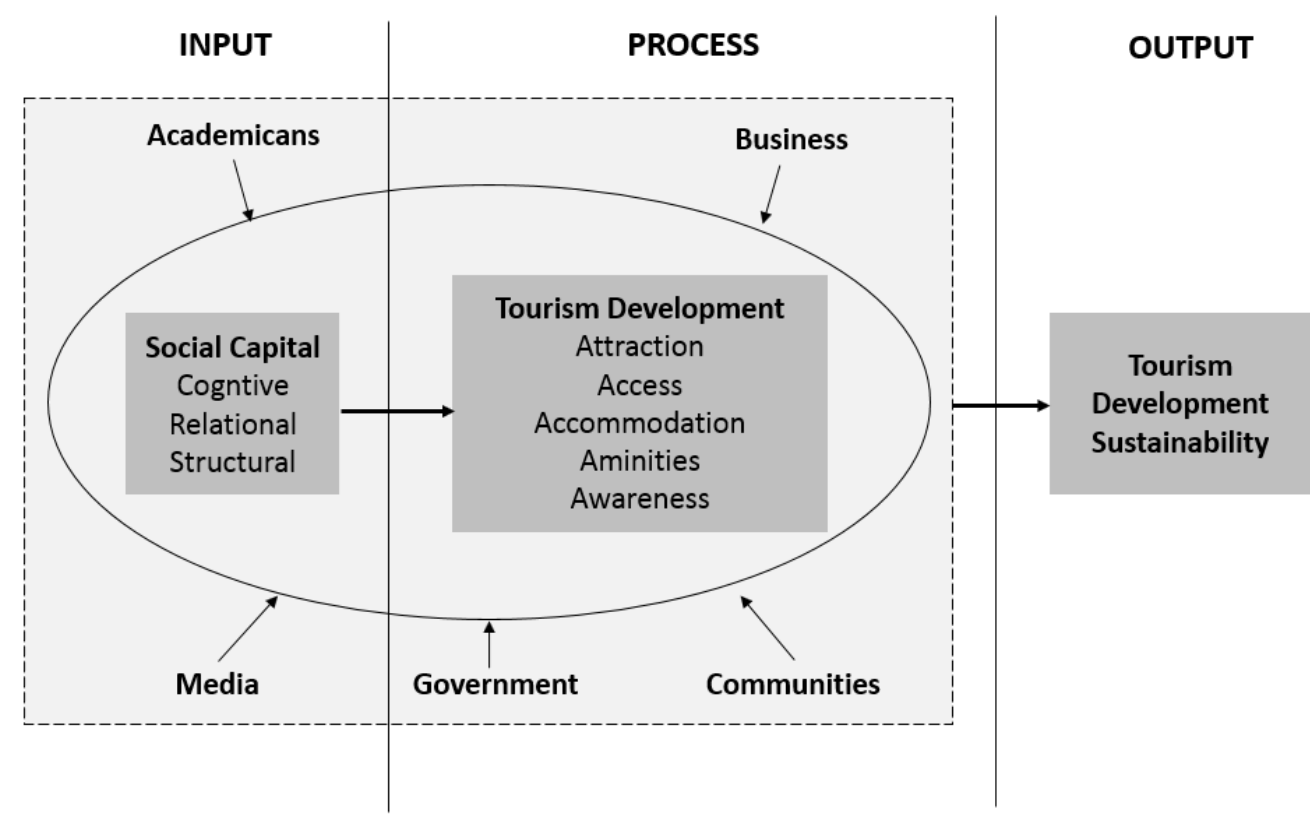

Figure 3 - Collaborative Governance Model in Urban tourism Development 
Eurasia: Economics \& Business, 1(19), January 2019

DOI https://doi.org/10.18551/econeurasia.2019-01

\section{CONCLUSION}

Research result indicates that social capital has an important role in building and developing urban tourism. Nevertheless, stakeholders support is needed to strengthen the social capital of local communities. Furthermore, social capital also plays an important role in the development of tourist destinations, especially related to developing attractions, amenities, and awareness. The process of developing a tourist destination will be more optimal if it involves stakeholders. Stakeholders may conduct collaboration in building and developing urban tourism through a collaborative governance approach in realizing sustainable tourism. Further research is needed on the importance of social capital in the successful application of tourism sector collaborative governance.

\section{REFERENCES}

1. Bramwell, B., \& Lane, B. (2011). Critical research on the governance of tourism and sustainability. Journal of Sustainable Tourism, 19(4/5), 411-421.

2. Carayanis, G.E., Barch, T., Campbell, D.S.J. 2012. The quintuple helix innovation model: Global warming as a challenge and Driver for Innovation, Journal of Innovation and Entrepreneurship, ISSN 2192-5372.

3. Cooper, C.C., 2000. Tourism: Principles and Practice, Second Edition, Longman, England.

4. Fan, D. X., \& Hsu, C. H. 2014. Potential mainland Chinese cruise travelers' expectations, motivations, and intentions. Journal of Travel \& Tourism Marketing, 31(4), 522e535

5. Fernanda, F. \& Kusuma, A.L. 2017. Kreativitas Masyarakat Kota Malang Dalam Membentuk Identitas Kota. FBS Unesa.

6. Gursoy, D., Chi, C. G., \& Dyer, P. (2010). Locals' attitudes toward mass and alternative tourism: the case of sunshine coast, Australia. Journal of Travel Research, 49 (3), 381 394.

7. Lorio, M. \& Corsale, A. Rural tourism and livelihood strategies in Romania. J. Rural Stud. 2010, 26, 152-162.

8. Johannesson, G., Skaptadottir, U. D., \& Benediktsson, K. (2003). Coping with social capital? The cultural economy of tourism in the North. Sociologia Ruralis, 43(1), 3-16

9. Jones, S. (2005). Community-based ecotourism-The significance of social capital. Annals of Tourism Research, 32(2), 303-324.

10. Liu, S., Cheung, L.T.O., Lo, A., Fang, W. 2018. Livelihood Benefits from Post-Earthquake Nature-Based Tourism Development: A Survey of Local Residents in Rural China.

11. Liu, J.C. \& Var, T. 1986. Resident attitudes toward tourism impacts in Hawaii. Ann. Tour. Res., 13, 193-214.

12. Miles, M. B., Huberman, A. M., \& Saldana, J. (2013). Qualitative data analysis. SageMehta, J.N.; Kellert, S.R. Local attitudes toward community-based conservation policy and programmes in Nepal: A case study in the Makalu-Barun conservation area. Environ. Conserv. 1998, 25, 320-333.

13. Pomering, A., Noble, G., \& Johnson, L.W. (2011). Conceptualizing a contemporary marketing mix for sustainable tourism, Journal of Sustainable Tourism, 19:8,953-969, DOI: 10.1080/09669582.2011.584625.

14. Santosa, E.B. \& Therik, L.V. (2016). Faktor Penentu Bertempat Tinggal pada Kawasan Kumuh di Kota Malang Berdasarkan Teori Doxiadis. Tata Loka, 18(4): p. 261-273.

15. World Economic Forum. 2017. The travel and tourism competitiveness report.

16. Zhao, W., Ritchie, J.R.B., Echtner, C.M. (2011). Social Capital and Tourism Entrepreneurship, Annals of Tourism Research, Vol. 38, No. 4, pp. 1570-1593. 